\title{
Evaluation of the lasting impacts on employability of co-operative serious game-playing by first year Computing students: An exploratory analysis
}

\author{
Jyoti Bhardwaj \\ School of Computing \\ Edinburgh Napier University \\ Edinburgh, Scotland \\ j.bhardwaj@napier.ac.uk
}

\begin{abstract}
This paper reports a case study of co-operative, small-group, game-based learning by a cohort of undergraduates on a range of computing programmes, during the first trimester of their first year. Game-based learning in the form of a totalenterprise business simulation is presented here as a medium to promote self-efficacy and employability through teamwork, presentation skills and greater self-confidence, with a possible relationship with improved work placement and graduate employment opportunities. The simulation is implemented to engender friendships amongst new students, in order to foster resilience and help prevent isolation.
\end{abstract}

Appended is a discussion of the results of a small-scale exploratory evaluation of the benefits of the simulation experience on aspects of self-efficacy, as reported by those students who took the module in session 2010/11 and remain on the course in the final year of their degree.

The study's findings are mixed: although the evidence for SimVenture being beneficial in gaining a placement is weak, respondents consider it enjoyable, a valuable learning experience, and cite its importance in gaining presentation skills, improving teamworking, making friends, and indirectly supporting the value of embedding simulations within meaningful learning activities to promote employability.

Keywords-employability; game-based learning; small group; simulation; self-efficacy; friendship

\section{INTRODUCTION}

Graduate employability remains a problematic, multidimensional aspiration for higher education institutions beset, for example in the UK, by greater competition for qualified entrants who bring in government funding. To help applicants choose their course, the UK-government sponsored website Unistats [1] details individual course performance indicators, and prominently displays "average salary six months after the course", the percentage of those working six months after the course who are in a "professional or managerial" job, and allows online comparison with other institutions. Prospective students and their anxious parents burden institutions with the expectation that the chosen degree course will deliver, in exchange for their investment of time and money, a graduate job - professional or managerial -at the end of it.
A definition of graduate employability that is arguably more meaningful to students and parents than a stark percentage next to a degree title, is: "a set of achievements, skills, understandings and personal attributes - that make graduates more likely to gain employment and be successful in their chosen occupations, which benefits themselves, the workforce, the community and the economy [2]. In 2009, the main employers' organisation in the UK, the Confederation of British Industry, collaborated with Universities UK, the higher education representative body, to formulate a list of employability skills which was publicised widely: selfmanagement; teamworking; business and customer awareness; problem solving; communication and literacy; application of numeracy; and application of information technology [3].

In UK universities, the task of incorporating employability into programme learning outcomes often falls to course leaders responsible for curriculum development and the consolidation students'n learning from year to year. The Higher Education Academy's "framework to support to support higher education institutions in embedding employability" [4] is based in part on the research literature on employability and its components, including self-efficacy [5], as well as the CBI-Universities UK employability skills document [3]. It gives guidance to academics in mapping learning activities on their programme to elements of employability. Scottish benchmark statements, relevant to the context of the author's institution, were formulated in 2004 and remain current advice: to embed employability within the curriculum; to enhance students' employability through the co-curriculum; and to engage employers in developing the curriculum [6].

This exploratory study presents an initiative to embed employability in the first year computing curriculum common to six degree courses of a university School of Computing, by means of a total enterprise, business simulation-centred learning activity undertaken over the course of a semester in groups, and assessed by group presentation.

\section{LEARNING CONTEXT OF THE SIMULATION}

The simulation forms the practical element of the Information Systems in Organisations (ISO) module, and is worth $40 \%$ of the module mark. Classes take the form of a 
weekly, two-hour, facilitated lab session with over the course of a semester. Whereas use of simulations in business organizations is characterized by at times minimal intervention by a session facilitator - indeed, there may be no face-to-face contact between player and facilitator - Liu, Cheng and Huang [7] cite evidence that players in educational settings with greater support often interact with simulations simply on a superficial and playful level, thereby weakening the effectiveness of learning [8] and that educators need to provide additional instructional supports [9] [10], suggesting that learning activities need to be well designed.

The subject-specific learning of the module includes fundamentals of business organization, general systems theory, and IT applications to support decision making, communication and B2B commerce, delivered in formal twohour lectures within the same module, and assessed by 40 multiple choice questions worth $40 \%$ of the overall module mark. The final element of the module is a written report based on a site visit, worth $20 \%$.

\section{APPLICATION OF THE SIMULATION}

The focus of the practical element of ISO is the use of SimVenture [11], a total enterprise, scenario-based simulation developed in the UK by Venture Simulations Ltd and used in higher and further education institutions and businesses, mainly in the UK. SimVenture is marketed as "an authentic business simulation [to] engage people in a deeper, richer learning experience and develop lasting business, enterprise and entrepreneurial talent" [11].

In the scenario, the player sets up, manages and grows a small business manufacturing computers. Working in simulated monthly cycles, the player makes decisions in four areas of business (organisation; sales and marketing; finance; and operations), runs a month, sees the impact of his or her actions on profit, cashflow and other indicators, and receives feedback on performance. The simulation rewards decisions based on market, competitor and customer research and response to performance feedback, rather than on guesswork. The challenge is to generate enquiries, sales and orders and build a successful firm within the simulation's 36 month limit.

Research into the benefits of using simulations to convey subject-specific knowledge is extensive [7]. However, in this instance, O'Hara's advocacy of a less deterministic "ingredients list" approach to the construction of a teaching framework was adopted, where "the aims of any pedagogy must focus less on fixed and predetermined outcomes, and more on open-ended emergent outcomes" [12]. "...it is misleading to focus on employability skills within education as merely a set of strategic tools because this approach undermines the aims and processes of education" [13].

Our intention at first presentation in 2009 was to implement the simulation as more than a means of instruction in business fundamentals and entrepreneurial skills. The arguments for connecting enterprise education with employability in the design of curricula has long been made [14]. Here, however, the simulation-centred activity also provides a medium for incorporating employability dimensions such as oral and personal presentation skills, teamworking abilities and time management [3] by organizing the simulation as a small-group activity, and assessing it by means of group presentation.

Learning outcomes of this module associated with enhancing students' employability are: the practise of purposeful co-operation; reflection on decision making; synthesis of information to incorporate business data; and design and giving of oral presentations, thereby improving engagement and self-confidence in presenting themselves. The need for these aspects has been apparent for several years and is confirmed in the UK's National Student Survey (NSS), which questions final year students in all publicly funded Higher Education Institutions in England, Wales, Northern Ireland, and Scotland. This survey differs from the NSSE used in North America, in measuring satisfaction with the course rather than engagement. In 2012, of the 20 disciplines included in the NSS, only Mathematics gave a more negative response than Computing students to the statement "The course has helped me to present myself with confidence" [15].

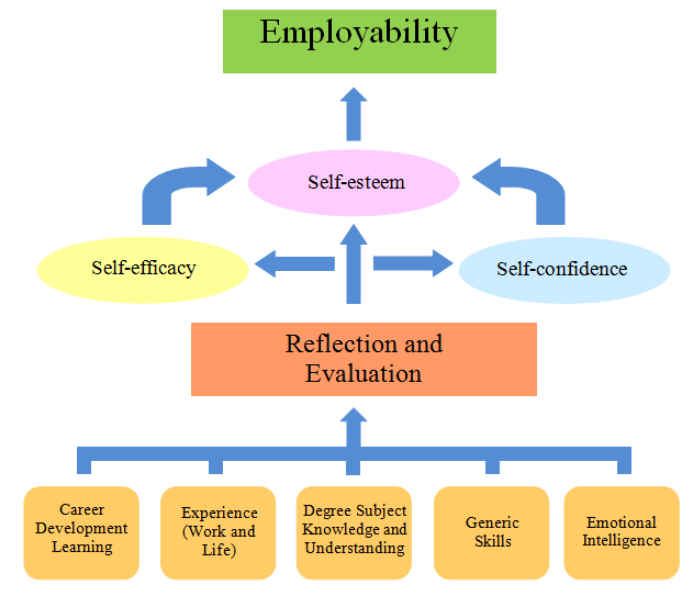

Fig. 1 Practical model of employability (adapted from [16])

The three closely-linked 'Ss' of self-efficacy, selfconfidence and self-esteem provide a crucial link between knowledge, understanding, skills, experience and personal attributes, and employability [16].

The improvement in employability is aimed not only at graduate careers, but also, in this institution, at equipping students to compete for and gain a twelve-month work placement at the end of second year. Students who have been on work placement enjoy beneficial impacts on self-efficacy [17] and "experiential action learning methods combined with direct work experience" is proposed as effective in developing employability [2]. Fostering students' own social and human capital in this way [18] sharpens their ability to capitalise on beneficial fortuities [19] and gain desirable graduate traineeships and positions on finishing their course.

The simulation element is assessed by a series of three group presentations during weeks 5,8 and 11 of the semester, and the total presentation marks are worth $40 \%$ of the final module mark. Norms and expectations in regard to personal presentation are communicated in advance but established at the first feedback opportunity, eg, marks and feedback are given for the team's personal appearance; oral delivery and 
demeanour; co-operative work and sharing of presentation tasks; sequencing and rehearsal of activities.

Feedback is delivered face-to-face at the presentation, supplemented by handwritten notes on a prepared marksheet (carbon copied to keep a record) awarding marks for structure, company identity, individual and team performance, decision making, problem solving, high quality slides, summary data intelligently presented in self-created Excel charts and other criteria. The handwritten feedback can be taken away by the members to discuss amongst themselves or have elaborated upon by the SimVenture lab facilitator. Though time is short, with only two or three minutes of face-to-face feedback available before the next group must enter and do its presentation, discussion with assessor is vital in allowing negotiation of marks allocation - more committed group members seeing "social loafers" or free-riders receive the same marks as them can sour their groupwork experience [20]. Discussion also performs the same beneficial interaction between student and tutor as the face-to-face, interactional model of study amongst face-to-face collaborating students [21].

As part of the final presentation, groups are tasked with giving a critical evaluation of their co-operation and teamwork during the previous ten weeks of being a company, to signal the importance of reflecting on these employability attributes [13].

Of particular relevance when arguing the case for the use of active learning through simulations as a component of efficacy beliefs in individuals is Bandura's explanation [19] [22] of mastery experiences, vicarious experiences provided by social models and social persuasion.

In the absence of the opportunity for first year undergraduates to establish and run a small business in real life, a total enterprise simulation offers those students a mastery experience in making financial, operational, design and supervisory decisions for 36 cycles. To reinforce this, presentations are carried out "in character", with team members acting in their company roles.

Bandura asserts that mastery experiences are the most effective way of creating a strong sense of self-efficacy with the result that they play, as Dacre Pool and Sewell argue, a vital role within employability [16]. Indeed, self-efficacy itself may be a valuable aspect of a student's employability: Pollack and Lilly [23] suggest that a student with higher self-efficacy may be more employable than a similar student with equal, or even slightly superior, objective skill levels. On the other hand, Brennan and Vos have found that, whilst the acquisition of subject-specific skills by means of a simulation may be improved measurably, there may be no improvement in selfefficacy related to these tasks [24].

The timing of SimVenture sessions is significant: it begins in the week after induction and is incorporated into a semesterlong module. SimVenture has been run deliberately early on in the students' courses, and, depending on their timetables, SimVenture may be these students' first lab session at university. The aim has been to engender supportive peer group relationships early on, recognised by Wilcox, Winn and
Fyvie-Gauld [25] as an enabling factor for successful transition into $\mathrm{HE}$ and essential for student retention. The UK Higher Education Statistics Agency reports that computing-related subjects suffer from the poorest retention rate amongst all disciplines, regardless of age and entry qualifications: entrants to higher education in 2010/11 who were least likely to be in higher education in 2011/12 were studying computer sciences, a situation that has persisted for some years [26].

Dacre Pool and Qualter [27] argue the case for interventions that help students to develop Emotional Intelligence, citing surveys of employers over the last two decades that consistently report employability skills predicted by EI, such as communication and team-working, as highly desirable in graduate recruits, e.g. [3] and [2].

\section{FOSTERING FRIENDSHIPS}

SimVenture is designed for a single player who makes all the decisions, to simulate as closely as possible the experience of a sole trader setting up a small business; here, it is run as a small-group, co-operative venture (default group size of three) with decision making for particular functions appropriated by various group members. Echoing Hermens and Clarke's conclusions [29] regarding use of simulations, we reasoned that "interactive pedagogies must be introduced into the learning context that $[\ldots]$ with regards to the group dynamics and human relations".

Small groups were favoured over larger groups in spite of the difficulties of administering and monitoring the attendance of so many individual company teams in a cohort which in most years exceeded 100 students (for example, in 2013-14, 121 students were divided into 46 groups). This was to minimise the opportunity for less motivated students to freeride on the efforts of other group members, to discourage absenteeism, foster engagement, and to encourage beneficial whole-group interaction, mutual support and feedback. Records show that attendance over the 13 weeks of the ISO module, attendance averaged at $90.3 \%$.

Although an explicit aim of running SimVenture as a small-group activity has been to encourage friendships, implementing it in this format is a risk, as groupwork is not universally popular amongst students, with free-riding by noncontributing group members causing the greatest concern in a recent attitudinal survey [20]. Additionally, Hillyard, Gillespie and Littig found that negative attitudes to groupwork amongst undergraduates were strongly influenced by negative groupwork experiences prior to university [30], over which the designer of the university learning activity can have no influence, except to override with newer, better experiences.

Allan, McKenna and Dominey carried out an interesting study [31] that correlates academic outcome with mental resilience in inductees to $\mathrm{HE}$, at a post-1992 institution similar to that of this study. A notable component of resilience is measured using the item "close and secure relationships" of the Connor-Davidson Resilience Scale, though the scale's authors themselves acknowledge that "it is possible to perform well in one area in the face of adversity (e.g., work) but to function poorly in another (i.e., interpersonal relationships)" [32]. There is some evidence for the protective role that friend 
support plays against academic stress amongst undergraduates [33] and that loneliness correlates with factors of learning burnout [34].

Interestingly, one of Allan, McKenna and Dominey's findings [31] is that the positive correlation between resilience and academic achievement is greater in females, and less functional and more convoluted for males, thereby arguing for different pedagogical approaches for male students. They repeat Pollack's proposition [35] that undergraduate males may 'present a "mask of bravado or pseudo-resilience' which may project confidence yet hide a troubling sense of isolation". Given the 9:1 ratio of male to female students in every ISO cohort since 2009, it was of special concern that students prone to isolation through lack of social confidence should have the chance of friendship fostered.

It might therefore seem intuitive to allow students to form their own SimVenture groups, whilst paying attention to preparing members for groupwork [36]. In fact, groups are randomly allocated in the first lab session, with the facilitator giving a brief introduction to SimVenture, then dividing students into threes simply according to where they have sat down. Whilst this appears draconian, the same rule applies to all students; this provides a benign compromise in allowing those students who have already formed friendships and chosen to sit together for the first lab to remain in their group, whilst, crucially, those who haven't yet made a friendly connection are allotted a readymade work group. This prevents the exclusion by fellow students, deliberate or unconscious, of those who are seen as less attractive or intelligent, those who lack social confidence, and those who may be assumed to be non-native English speakers [37], in an effort to prevent incipient isolation.

\section{EVALUATION STUDY}

A study was carried out using a purposive sample of final year students to establish the extent to which they associate their experience with SimVenture, over three years earlier, with improved employability, asking specifically amongst its components about teamworking [3]. In addition, mention is made of self-confidence and self-efficacy to test the proposal that improvement in these is a factor in employability [16] and about friendship, to examine the use of SimVenture to engender friendships and help to minimise isolation amongst new entrants to the university. The evaluation is in addition to routine monitoring of the module through a student feedback form administered in all School of Computing modules during the closing weeks of the semester, which asks mostly free-text questions, and to which there were 63 responses in 2010-11:

1. What is your overall impression of the module? (very good - very poor)

2. What was most rewarding about the module?

3. What was least rewarding about the module?

4. Was your feedback on assessments useful and timely?

5. What other comments would you like to make about this module?
The questionnaire referred to in this study was constructed using Survey Monkey [38] and administered online during March 2014. Respondents were sent an e-mail request to complete the questionnaire online as soon as they had time, acknowledging that it was a busy time of year for coursework and final year dissertations, which itself precluded using interviews for data gathering. A follow-up reminder e-mail was

TABLE I. EVALUATION QUESTIONS

\begin{tabular}{|c|c|c|}
\hline No & Question & Scale \\
\hline 1 & $\begin{array}{l}\text { To what extent do you agree with the } \\
\text { following statement: "I found doing } \\
\text { SimVenture enjoyable"? }\end{array}$ & $\begin{array}{l}\text { Strongly agree - } \\
\text { Strongly disagree }\end{array}$ \\
\hline 2 & $\begin{array}{l}\text { To what extent do you agree with the } \\
\text { following statement: "I found doing } \\
\text { SimVenture useful"? }\end{array}$ & $\begin{array}{l}\text { Strongly agree - } \\
\text { Strongly disagree }\end{array}$ \\
\hline 3 & $\begin{array}{l}\text { To what extent do you agree with the } \\
\text { following statement: "SimVenture was a } \\
\text { valuable learning experience for me"? }\end{array}$ & $\begin{array}{l}\text { Strongly agree - } \\
\text { Strongly disagree }\end{array}$ \\
\hline 4 & $\begin{array}{l}\text { To what extent do you agree with the } \\
\text { following statement: "I found doing } \\
\text { SimVenture helped me in other or later } \\
\text { modules"? }\end{array}$ & $\begin{array}{l}\text { Strongly agree - } \\
\text { Strongly disagree }\end{array}$ \\
\hline 5 & $\begin{array}{l}\text { To what extent do you agree with the } \\
\text { following statement: "I found doing } \\
\text { SimVenture helped me outside } \\
\text { university"? }\end{array}$ & $\begin{array}{l}\text { Strongly agree - } \\
\text { Strongly disagree }\end{array}$ \\
\hline 6 & $\begin{array}{l}\text { In what ways did SimVenture help you, } \\
\text { either inside or outside university? } \\
\text { (Please select all that apply) }\end{array}$ & $\begin{array}{l}\text { - self-confidence } \\
\text { - presentation } \\
\text { skills } \\
\text { - teamworking } \\
\text { abilities } \\
\text { - social skills } \\
\text { - motivation } \\
\text { - time } \\
\text { management } \\
\text { skills } \\
\text { - did not help me }\end{array}$ \\
\hline 7 & $\begin{array}{l}\text { Did you make any friendships as a result } \\
\text { of doing SimVenture? }\end{array}$ & Yes/No \\
\hline 8 & $\begin{array}{l}\text { To what extent was making friends } \\
\text { through SimVenture important to you? }\end{array}$ & $\begin{array}{l}\text { Very important - } \\
\text { Very } \\
\text { unimportant }\end{array}$ \\
\hline 9 & $\begin{array}{l}\text { Since doing SimVenture, have you } \\
\text { undertaken a work placement, or an } \\
\text { internship, or the Professional Practice } \\
\text { module? }\end{array}$ & Yes/No \\
\hline 10 & $\begin{array}{l}\text { To what extent was your experience or } \\
\text { learning from SimVenture helpful in your } \\
\text { placement, internship or Professional } \\
\text { Practice module? }\end{array}$ & $\begin{array}{l}\text { Very helpful - } \\
\text { Very unhelpful } \\
\text { I have not done } \\
\text { placement, etc }\end{array}$ \\
\hline 11 & $\begin{array}{l}\text { If you answered positively to Question } \\
10 \text {, please relate an incident, situation or } \\
\text { occasion when your experience or } \\
\text { learning from SimVenture was useful to } \\
\text { you. }\end{array}$ & Free-text \\
\hline 12 & $\begin{array}{l}\text { Since doing SimVenture, have you } \\
\text { applied for and gained a full-time or part- } \\
\text { time job of any kind? }\end{array}$ & Yes/No \\
\hline 13 & $\begin{array}{l}\text { To what extent was your experience or } \\
\text { learning from SimVenture helpful in } \\
\text { gaining a full-time or part-time job? }\end{array}$ & $\begin{array}{l}\text { Very helpful - } \\
\text { Very unhelpful } \\
\text { I have not had a } \\
\text { job }\end{array}$ \\
\hline 14 & $\begin{array}{l}\text { If you answered positively to Question } \\
13 \text {, please relate an incident, situation or } \\
\text { occasion when your experience or } \\
\text { learning from SimVenture was useful to } \\
\text { you. }\end{array}$ & Free-text \\
\hline
\end{tabular}




\begin{tabular}{|c|l|l|}
\hline No & \multicolumn{1}{|c|}{ Question } & \multicolumn{1}{c|}{ Scale } \\
\hline 15 & $\begin{array}{l}\text { Finally, thank you for taking the time and } \\
\text { trouble to answer this questionnaire, and } \\
\text { please feel free to add any other } \\
\text { comments regarding your experience of } \\
\text { SimVenture. }\end{array}$ & Free-text \\
\hline
\end{tabular}

sent a week later. Although it was acknowledged that a higher response rate would be assured by asking respondents face-toface and making time available during a class when they would be present, it was felt that the sample population was a minority of the class, and to devote class time and attention to an online questionnaire for them alone would be excluding and disruptive of other students' learning.The sample population consists of the 32 students who have remained on their course until the final year of undergraduate study in session 20132014, who took the ISO class during their first year. The sample is mainly drawn from an ISO class in session 2010-11 which numbered 75 students, an unusually small cohort; however, of the 32 , five have spent a year longer in elapsed time to reach their final year owing variously to re-sits, switching to part-time and suspending studies.

Consequently, these five are from the previous ISO cohort, session 2009-2010, which had 118 students. Student numbers in ISO were 153 in 2011-12; 126 in 2012-3; and 121 in 2013-4.

We examine the students' involvement with SimVenture and any relationship to their success in gaining a work placement at the end of their second year, their ability to find part-time employment during their studies, and self-reported perception of improvement in their own employability.

As can be seen from Table 1, questions are of mixed formats, though mainly on a 5-point Likert scale and closed questions. The main dimensions of questioning are: attitudes towards SimVenture; perception of SimVenture as helpful in six ways associated with employability; making friends through SimVenture; perception of learning from SimVenture being helpful in obtaining a work placement or job, or during the work placement or job. Of the sample of 32 final year students, 16 responded. Eight students responded during the first week, with the remaining eight responding over the following three weeks. A modest response rate was anticipated given the students were busy with coursework.

The first finding is that, disappointingly, fewer than 50\%, of the 2010-11 cohort are still on their course, indicating troublingly low retention, in spite of an average retention rate of $80 \%$ plus for first year cohorts over the period ISO has been taught. Follow-up investigation shows that a disproportionately large number of students who leave before graduating do so as a result of failure to complete second year. Graduating numbers do not decline, however, because of direct entrants into the senior $\left(3^{\text {rd }}\right.$ and $\left.4^{\text {th }}\right)$ years.

In addition to four responses to the free-text questions (11, $14,15)$ results from the questionnaire survey are that:

- Q1: SimVenture is seen as an enjoyable activity by 14 respondents (88\%), with two answering neutrally.

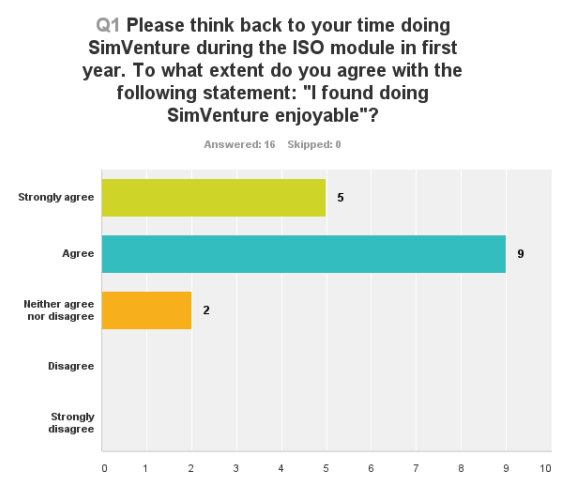

- Q2: It is seen as a useful activity by 10 respondents (63\%).

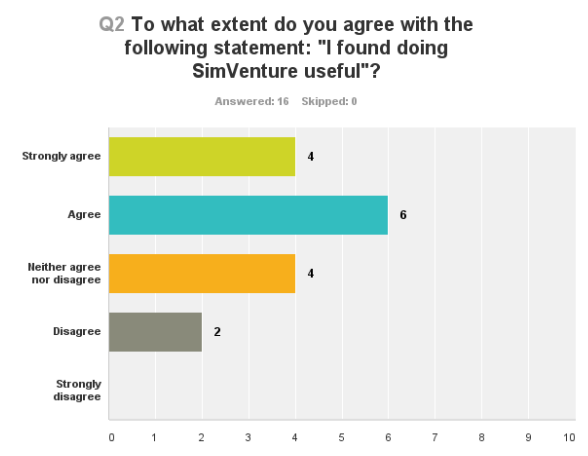

- Q3: It is seen as a valuable learning experience by 14 (88\%) respondents, with two disagreeing.

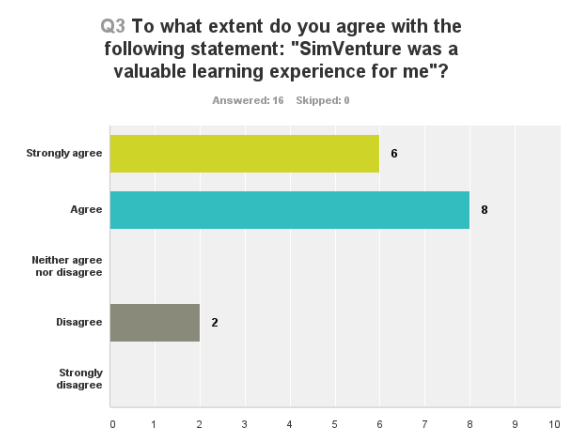

- Q4: Only 5 respondents (31\%) agree that SimVenture helped them in other modules, 6 respondents (38\%) disagree, and another 5 (31\%) are neutral.

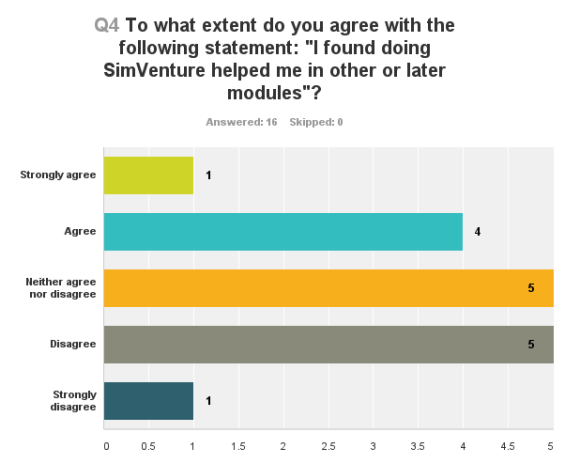


- Q5: 7 respondents (44\%) agree that doing SimVenture helped them outside University, balanced against 7 (44\%) who are neutral and 2 (13\%) who disagree.

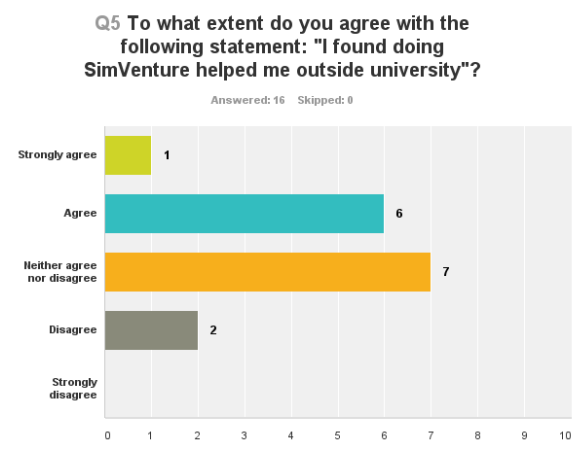

- Q6: SimVenture improved the presentation skills of 14 out of 15 respondents $(93 \%)$, and the teamworking skills of 13 $(87 \%)$ respondents. It improved the self-confidence of 9 $(60 \%)$ respondents, and the social skills of $6(40 \%) .4$ respondents $(27 \%)$. All 15 respondents who answered this question indicated that SimVenture helped them inside or outside university in at least one of these ways.

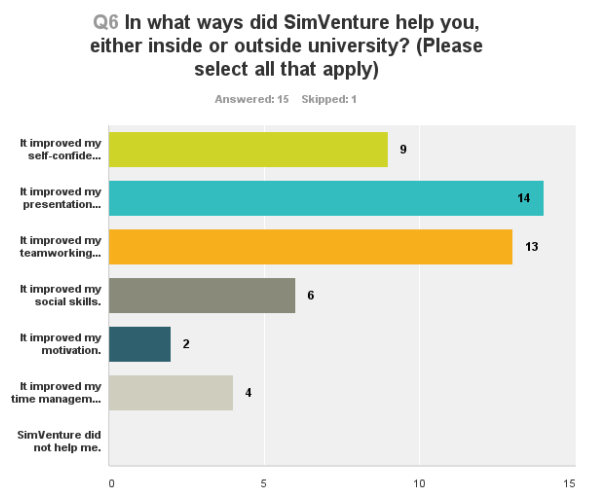

- Q7: 13 (81\%) respondents reported that they made friendships through SimVenture, whilst 3 (19\%) did not.

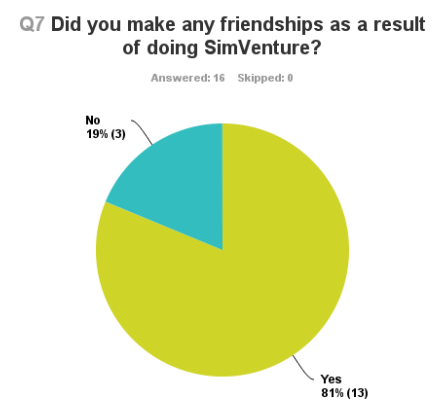

Q8: Making friends through SimVenture was important to 10 respondents $(63 \%)$. A further $5(32 \%)$ were neutral and for $1(6 \%)$ it was unimportant.

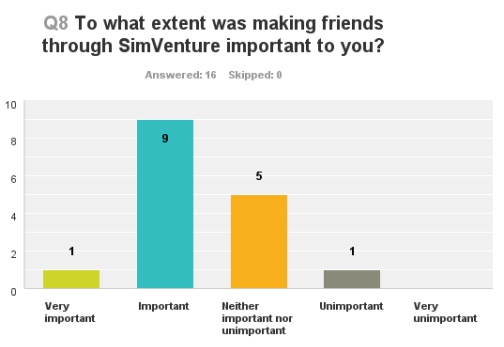

- Q9: Of the 16 respondents, 9 (56\%) did either a work placement, internship or a Professional Practice module. The remaining 7 (44\%) did not.

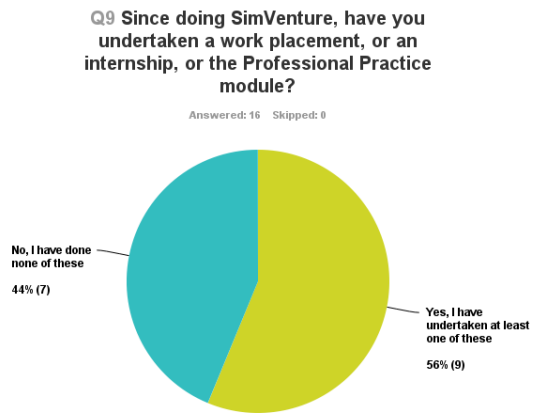

- Q10: 6 respondents (38\%) were neutral on the degree to which SimVenture was helpful during their placement. 4 (25\%) considered it helpful. 2 respondents answered this question using the scale, even though they had not done a placement.

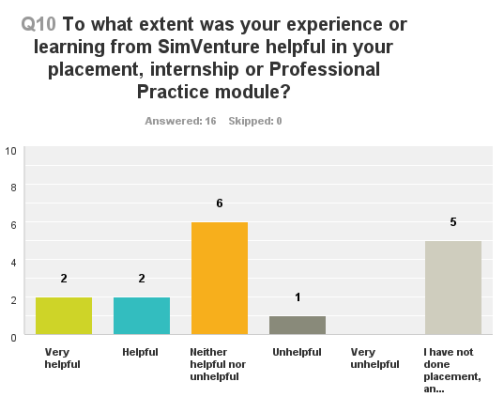

Free text answers to Q11 were: "it was helpful with my confidence in team meetings and discussing things. the presentations helped my confidence and team building"; "I was required to give a presentation while on placement to my whole department. The skills I learned in the ISO module were of huge benefit to me"; "On my WBL module I had to present a system I created to management. This process was made a lot easier though the completion of SimVenture"; "The social and presentation skills learned helped with presentations given on placement".

- Q12: 8 out of 16 respondents had obtained a full- or parttime job since they did SimVenture. 


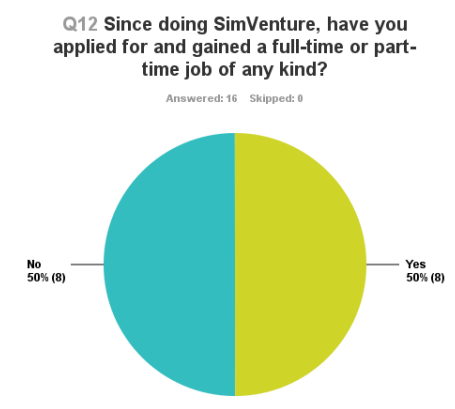

Q13: $2(13 \%)$ respondents stated that SimVenture had been unhelpful in helping them obtain a job. A further 6 were neutral. 2 respondents answered this question using the scale contradicting their earlier response that they had not done a placement.

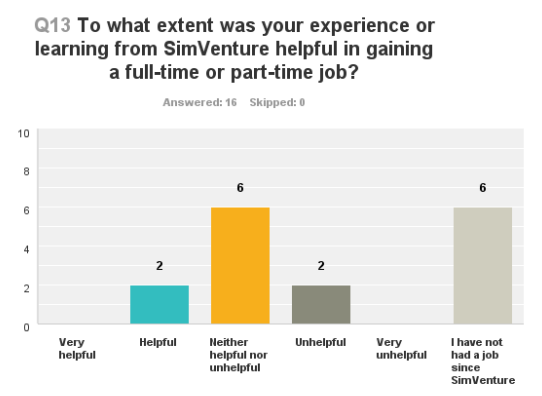

Free-text responses to Q14 were: "SimVenture experience helped me to summarise important information and deliver it effectively"; "I think confidence gained from the presentation aspect of SimVenture probably helped in the interview process".

Free-text responses to Q15 were: "you should find a way to let students run the software from home"; "I found Sim Venture very useful and feel it played a significant part to my success in academia and also in my professional development"; and "; "While I did not enjoy using the SimVenture program and found it finicky and strange I think the presentation and team working were useful skills to develop".

\section{DISCUSSION}

It was important when designing the evaluation questionnaire to establish clearly whether the respondent had found doing SimVenture enjoyable and useful, and whether it had been seen as a valuable learning experience. Respondents did indeed find it enjoyable but it can be argued that even if they did not also find it useful or a valuable experience, the mere fact of enjoyment could help ease them into university life [31], of particular importance to student retention and of value where, as in Scotland, the normal age of entry to university is only 17 .

Interestingly, whereas only 10 respondents found doing SimVenture useful and a further 4 were neutral, a greater number, 14, found it a valuable learning experience. The first figure could be explained by the ISO module featuring on the syllabus of six different degrees, varying from Software Engineering, through Computer Networks, to Business Information Systems, with some students feeling it was not relevant to their course of study. This finding is supported by the 2010-11 module questionnaire, where the small number of neutral respondents and sole negative response to "What is your overall impression of the module?" mention in the "any other comment" field that the module was not relevant to them.

The more positive response to "To what extent do you agree with the following statement: "SimVenture was a valuable learning experience for me"?" may signify that respondents differentiate between learning activities that are related to the content of their degree - which SimVenture was not, except perhaps for students on the Business Information Systems degree - and those activities which, more strongly in hindsight perhaps, foster the three S's of self-efficacy, selfconfidence and self-esteem [16] and that students themselves are able to see the value of non-subject specific activities as promoting employability [13].

The primary improvement reported by respondents in response to the question "In what ways did SimVenture help you, either inside or outside university? (Please select all that apply)" was to presentation skills. Results of the routine module questionnaire for ISO administered during session 2010-11, for which 63 responses were received, show that almost all the comments under "What did you find most rewarding about the module" referred either to SimVenture or to "presentations". It appears that in the period immediately following the series of three presentations, respondents felt the most rewarding aspect of the module was the opportunity to practise and improve presentation skills, and that this remains valid three years later.

Being able to deliver presentations with confidence during placements, increases the students' ability to capitalise on beneficial fortuities [19]. The ultimate goal in improving this during placement or work experience is to be better placed on graduation to deal effectively with a computing job market perceived, from the higher education perspective, as employerdriven, and requiring the kind of self-presentation skills and confidence not generally associated with computing course students [15].

"Teamworking abilities" is the second most common response to the question "In what ways did SimVenture help you, either inside or outside university?". It is cited variously as a key component of employability [3] [23]. The use of SimVenture to support employability in this respect is well supported.

The aim of this evaluation was to assess the long term benefits of SimVenture as a vehicle or employability skills, for their own sake and to improve students' chances of gaining a work placement or job [17]. Although the evidence for SimVenture being beneficial to gaining a placement is weak only 4 out of the 9 students who did placement rated it as very helpful or helpful - the comments in the free-text answer were positive, with each one mentioning presentations, and two mentioning confidence. 
An implicit aim of using SimVenture as the practical element of the ISO module was to provide an inclusive means of encouraging friendship through purposeful interaction, which would in turn provide even socially-unconfident students with a friendship network [25] to help ease the transition to university, and to provide support [33] in times of need. The high number of respondents who made friends through SimVenture attests to the gratifying success of this strategy, which is supported by the relatively high number of respondents who think making friends was important.

Whilst the aim of small-group interaction here is to foster engagement and ultimately to promote retention, the small size of the study sample shows two things: that without a comprehensive study which gathers data both immediately on completion of the module and follows those students till graduation and beyond, any post-hoc evaluation will be merely interesting rather than conclusive. The small sample size also attests to the cumulative effects of poor retention rates in subsequent years of the degree, which places any research on the role of friendship on resilience and persistence in the context of other factors in non-completion - performance, economic necessity, family reasons.

\section{CONCLUSION}

The implementation of SimVenture in the context of this first-semester, first year module supports the proposal that educators can scaffold other learning using business simulations, and that it can play a role in establishing relationships amongst participants. Despite the small sample, responses indicate that designing a learning experience that facilitates small-group interaction has worked to foster friendship. Responses also support the general proposal that business simulations are an enjoyable medium for improving employability skills such as presentations. A higher response rate than 16 out of 32 would have strengthened all the findings.

That said, this study has been extremely useful in forming the exploratory stage of a planned longitudinal, cohort-wide study into the role that friendship networks play in the resilience, persistence and employability of computing students. The planned research will assess successive cohorts who undergo the small group learning experience on the ISO module and elicit their experience of friendship gained during the module and outside university, and their self-reported improvements in employability skills immediately after delivery of the ISO module. It will further test whether these correlate with gaining a work placement at the end of year two or part-time employment or an internship at any stage.

The study will at each stage ask participants about the role that friendship has played in them persisting thus far, and follow each cohort through their degree to completion and final employment destination.

\section{Works Cited}

[1] Unistats, "The official website for comparing UK higher education course data," [Online]. Available: http://unistats.direct.gov.uk/. [Accessed 20 April 2014].

[2] A. Pegg, J. Waldock, S. Hendy-Isaac and R. Lawton, "Pedagogy for Employability," 2012. [Online].
Available:

http://www.heacademy.ac.uk/resources/detail/employabi lity/pedagogy_for_employability_update_2012.

[Accessed 4 April 2014].

[3] Universities UK; CBI, "Future fit: Preparing graduates for the world of work," 2009. [Online]. Available: http://www.universitiesuk.ac.uk/highereducation/Docum ents/2009/FutureFit.PDF. [Accessed 20 April 2014].

[4] D. Cole and M. Tibby, "Defining and developing your approach to employability:A framework for higher education institutions," [Online]. Available: http://www.heacademy.ac.uk/assets/documents/employa bility/Employability_framework.pdf. [Accessed 24 April 2014].

[5] A. Bandura, "Self-efficacy: Toward a unifying theory of behavioral change," Psychological Review, vol. 84, no. 2, pp. 191-215, 1977.

[6] "Benchmarking employability: A Scottish perspective," 2004. [Online]. Available:

http://www.enhancementthemes.ac.uk/enhancementthemes/completed-enhancement-themes/employability. [Accessed 4 April 2014].

[7] C. Liu, Y. Cheng and C. Huang, "The effect of simulation games on the learning of computational problem solving," Computers \& Education, vol. 57, no. 3, p. 1907-1918, 2011.

[8] R. E. Mayer, "Should there be a three-strikes-rule against pure discovery learning? A case for guided methods of instruction," American Psychologist, vol. 59, pp. 14-19, 2004.

[9] M. Yamen, C. Nerdel and H. Bayrhuber, "The effects of instructional support and learner interests when learning using computer simulations," Computers \& Education, vol. 51, no. 4, pp. 1784-1794, 2008.

[10] P. Wouters and H. Oostendorp, "A meta-analytic review of the role of instructional support in game-based learning," Computers \& Education, vol. 60, no. 1, pp. 412-425, 2013.

[11] Venture Simulations, "SimVenture," [Online]. Available: http://simventure.co.uk/index.php. [Accessed 23 April 2014].

[12] M. O'Hara, “Strangers in a strange land: Knowing, learning and education for the global knowledge society," Futures, vol. 39, no. 8, pp. 930-941, 2007.

[13] S. Deeley, "Summative co-assessment: A deep learning approach to enhancing employabiity skills and attributes," Active Learning in Higher Education, vol. 15, no. 1, pp. 39-51, 2014.

[14] D. Rae, "Connecting enterprise and graduate employability: Challenges to the higher education culture and curriculum?," Education + Training, vol. 49, no. 8/9, pp. 605-619, 2007.

[15] Higher Education Funding Council for England, "National Student Survey," 20 June 2013. [Online]. 
Available:

http://www.hefce.ac.uk/whatwedo/lt/publicinfo/nationals tudentsurvey/nationalstudentsurveydata/2012/.

[Accessed 28th March 2014].

[16] L. Dacre Pool and P. Sewell, "The key to employability: Developing a practical model of graduate employability," Education and Training, vol. 49, no. 4, pp. 277- 289, 2007.

[17] F. Purdie, T. McAdie, N. King and L. Ward, "In the right placement at the right time? An investigation of the psychological outcomes of placement learning,"

Procedia - Social and Behavioral Sciences, vol. 29, pp. 717-724, 2011.

[18] M. Fugate, A. Kinicki and B. Ashforth, "Employability: A psycho-social construct, its dimensions, and applications," Journal of Vocational Behavior, vol. 65, no. 1, pp. 14-38, 2004.

[19] A. Bandura, "Utilising beneficial fortuities and avoiding detrimental ones," Psychological Inquiry, vol. 9, no. 2, pp. 95-115, 1998.

[20] D. Hall and S. Buzwell, "The problem of free-riding in group projects: Looking beyond social loafing as reason for non-contribution," Active Learning in Higher Education, vol. 14, no. 1, pp. 37-49, 2013.

[21] S. Pillay and R. James, "The pains and gains of blended learning - social constructivist perspectives," Education + Training, vol. 56, no. 4, pp. 254 -270, 254 -270.

[22] A. Bandura, "Exercise of personal and collective efficacy in changing societies," in Self-Efficacy in Changing Societies, Cambridge, Cambridge University Press, 1995, pp. 1-45.

[23] B. Pollack and B. Lilly, "Gaining confidence and competence through experiential assignments: An exploration of student self-efficacy and spectrum of inquiry," Marketing Education Review, vol. 18, no. 2, pp. 55-66, 2008.

[24] R. Brennan and L. Vos, "Effects of participation in a simulation game on marketing students' numeracy and financial skills," Journal of Marketing Education, vol. 35, no. 3, pp. 259-270, 2013.

[25] P. Wilcox, S. Winn and M. Fyvie-Gauld, "It was nothing to do with the university, it was just the people': The role of social support in the first-year experience of higher education," Studies in Higher Education, vol. 30, pp. 707-722, 2005.

[26] Higher Education Statistics Agency, "Performance Indicators: Non-continuation following year of entry (table series 3)," 2013. [Online]. Available: http://www.hesa.ac.uk/index.php?option=com_content\& task=view\&id=2064\&Itemid=141. [Accessed 18 April 2014].
[27] L. Dacre Pool and P. Qualter, "Improving emotional intelligence and emotional self-efficacy through a teaching intervention for university students," Learning and Individual Differences, vol. 22, no. 3, pp. 306-312, 2012.

[28] A. Hermens and E. Clarke, "Integrating blended teaching and learning to enhance graduate attributes," Education + Training, vol. 51, no. 5/6, pp. 476-490, 2009.

[29] C. Hillyard, D. Gillespie and P. Littig, "University students' attitudes about learning in small groups after frequent participation," Active Learning in Higher Education, vol. 11, no. 1, pp. 9-20, 2010.

[30] J. F. Allan, J. Mckenna and S. Dominey, "Degrees of resilience: Profiling psychological resilience and prospective academic achievement in university inductees," British Journal of Guidance \& Counselling, vol. 42, no. 1, pp. 9-25, 2014.

[31] K. M. Connor and J. R. T. Davidson, "Development of a new resilience scale: the Connor-Davidson Resilience Scale (CD-RISC)," Depression and Anxiety, vol. 18, no. 2, pp. 76-82, 2003.

[32] S. Wilks and C. A. Spivey, "Resilience in undergraduate social work students: Social support and adjustment to academic stress," Social Work Education, vol. 29, pp. 276-288, 2010.

[33] S.-H. Lin and Y.-C. Huang, "Investigating the relationships between loneliness and learning burnout," Active Learning in Higher Education, vol. 13, no. 3, pp. 231-143, 2012.

[34] W. S. Pollack, "Sustaining and reframing vulnerability and connection, creating genuine resilience in boys and young males," in Handbook of resilience in children, New York, Springer, 2006, p. 65-77.

[35] L. Beccaria, M. Kek, H. Huijser, J. Rose and L. Kimmins, "The interrelationships between student approaches to learning and group work," Nurse Education Today, no. February, 2014.

[36] P. Strauss, A. U and S. Young, "'I know the type of people I work well with': Student anxiety in multicultural group projects," Studies in Higher Education, vol. 36, no. 7, pp. 815-829, 2011.

[37] Survey Monkey, 2014. [Online]. Available: https://www.surveymonkey.com/. [Accessed 24 April 2014].

[38] A. Pegg, J. Waldock, S. Hendy-Isaac and R. Lawton, "Pedagogy for employability," 2012. [Online]. Available: http://www.heacademy.ac.uk/assets/documents/employa bility/pedagogy_for_employability_update_2012.pdf. [Accessed 10 April 2014]. 